\title{
High Liquidity or Low Liquidity Is Better to Achieve High Profitability? Evidence from Banks in Central and Southern Europa
}

\author{
Gazmend Nure \\ Freie University of Berlin \\ E-mail: gnure@zedat.fu-berlin.de
}

Received: June 7, 2019 Accepted: July 30, 2019 Published: September 26, 2019

doi:10.5296/ifb.v6i2.14897ＵRL: http://dx.doi.org/10.5296/ifb.v6i2.14897

\begin{abstract}
This work investigated the impact of the bank's liquidity management in the profitability of the bank, considering the fact that different research has found that their relationship is negative in some other positive research. The relationship between these two components depends on the variables used to measure them. In this study are included commercial banks operating in southern and central Europe for the period 2009-2017. Following the study, it was possible to determine which is the optimal level of liquidity that gives us the highest level of profitability, and the results showed that not necessarily the high-level liquidity banks can achieve high-level profitability. The data had non-normal distribution, so as a technique of analysis non-parametric tests were used.
\end{abstract}

Keywords: bank liquidity, optimum, profitability, relationship, ROE, Equity, Cash ratio, Debt equity ratio 


\section{Introduction}

This study studies the relationship between liquidity and bank profitability in the South East Europe region. Both of these factors are very important for every financial institution as indicators indicating the diagnosis of any business whether it is healthy or not. This type of mechanism Intertwined has a parallel movement, any business that wants to maximize the profit of the shareholders (Patnaik \& Patnaik, M. 2005) considering not only investment but also financing and dividends, with the aim of optimizing of earnings (Bordeleau \& Graham, 2010), definitely on the other hand should manage its liquidity or ability to pay short-term liabilities (Salim \& Bilal 2016; Saleem \& Rehman 2011). Prudent liquidity management is vital to business operations by keeping it in the right settings between the two extreme edges. When excessive liquidity means fund accumulation and low profitability, insufficient liquidity or less than 1 indicates a lack of ability bankers to pay debts in the short term (Amengor, 2010) (Morrel, 2007). Often, liquidity management, though important to businesses, is misunderstood and overlooked, so it is very important to understand the nature and impact of liquidity in business profitability (Fuertes et al., 2009).Various studies show that there is a link between liquidity and profitability. This study seeks to find out how this relationship is in the central and south European countries and which banks have the highest benefit those with high liquidity or low liquidity. Commercial banks as financial intermediaries absorb financial surpluses from depositors and make them available to borrowers. This investment activity carries risks and problems because the bank, on the one hand, seeks to maximize its profit through these investments and on the other hand the bank is exposed at all times to meet the obligations of its customers and depositors wishing to withdraw their savings. The problem lies in how banks choose the optimal level in which they can hold their assets in order to achieve both objectives together. Therefore, the objective of this research is to examine the effect of bank liquidity management on profitability in commercial banks in Central and Southern Europe, taking into account their need to maintain a greater balance between liquidity and profitability at the same time. The 2007-2008 financial crisis revealed that liquidity plays an important role in bank operations, but not only because it also has a direct impact on profitability (Lancaster \& Stevens, 1998; Lartey et al., 2009). Therefore, financial management decisions are very important in determining the level of liquidity of a bank with a view to maximizing its profit (Ibe, 2013). High liquidity ratios show a business financial power (Chandra, 2001), but the very high liquidity ratio also indicates the problems of bank mismanagement (Matarazzo, 2003). Therefore, the appropriate balance which avoids short-term liquidity pressures requires the removal of excessive or inadequate liquidity appropriate to the desired operating level of the bank (Bourzgarru et al., 2018).

\section{Literature Review}

The banking sector plays an essential role in the development of the business sector as well as of the economy as a whole. Banks as financial institutions carry out the role of financial intermediaries by collecting deposits from individuals and firms on one side and by providing these funds with loans to clients and institutions. The purpose of banks, like any business, is to maximize their profits by using as many of these resources but being conditioned by the 


\section{NI Macrothink}

fact that they have to be able to fulfill their obligations to customers in the short term. There are various controversies from researchers, who have come to different conclusions regarding liquidity management policies and their influence on banks' profitability. This problem will be part of our study, to determine whether there is a long-term influence on the banks' profitability? Is it better to have a high level of liquidity or a low level? What is the optimum level of liquidity to have a high level of profitability? Liquidity management is a very important part of the management's financial decisions, where efficient liquidity management is achieved when the bank is managing trade-offs between liquidity and profitability (Bhunia \& Khan, 2011). Profitability and profitability are two factors (Kosmidou, 2008). The high liquidity levels for banks are costly as they cause reductions in profitability (Fuertes \& Milne, 2012). Profitability and liquidity are two very important components for banking operations and prudent liquidity management is the main determinant of market value for a bank, as it has a direct effect on profit. Determining an optimal level of liquidity and profitability is not affected only by the asset management policy that the bank does, but also by the way the bank finances these resources. Figure 1 reflects the relationship between liquidity and profitability.

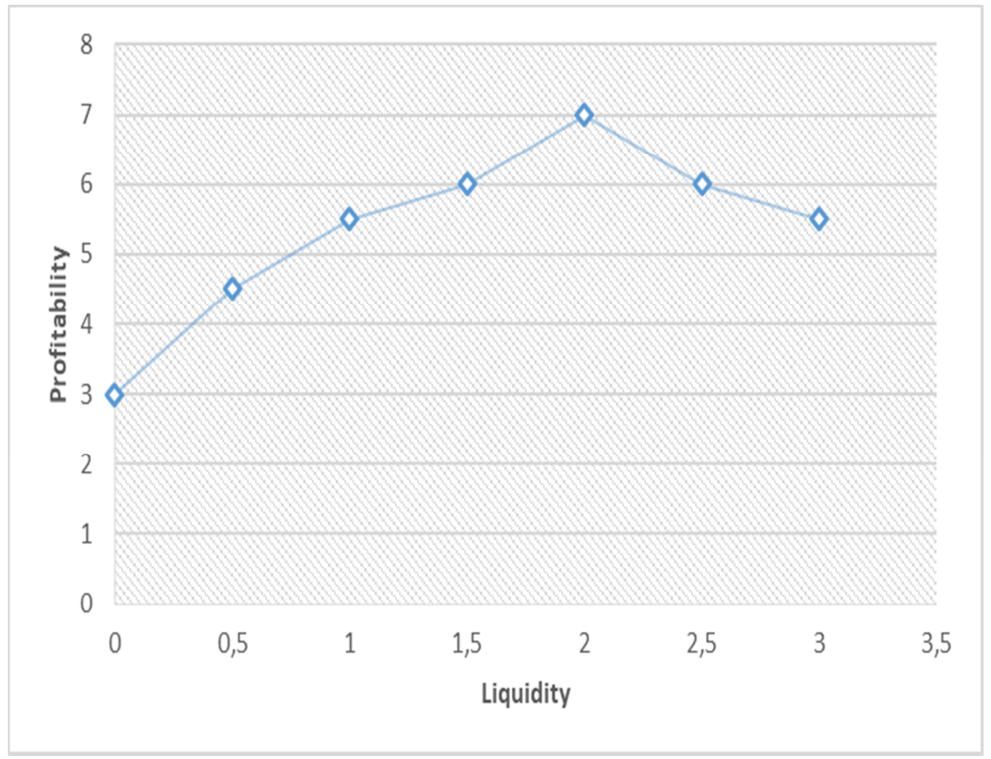

Figure 1. Liquidity -profitability relationship, source: Author own study

The liquidity value, which will give us the maximum profitability, is related to the determination of an optimal liquidity level. If we increase the value of liquid assets in the total assets, this will be accompanied by the increase in the level of liquidity but will also result in a decrease in profit. On the other hand, an increase in the level of short-term liabilities to the total of liabilities causes a decrease in the level liquidity, but contributes to increasing the level of profit. On the other hand, an increase in the level of short-term liabilities in total liabilities causes a decrease in the level of liquidity, but contributes to the increase in the level of profit. This negative relationship between liquidity and profitability 
(Gajdka \& Walinska, 2008) shows that when the level of liquidity falls below the optimum level of liquidity, it causes a decrease in profit but, on the other hand, places the bank on unmanageable positions to meet short-term liabilities over time (Wojciechowska, 2001).Good management of current assets and current liabilities can have a good influence on the profitability and the establishment of a bottom line is to build a balance between liquidity and profitability (Parmil \& Kumar, 2012). This equilibrium is seen as a condition for having financial stability for banks (Renato, Schwambach Vieira, 2010). An aggressive policy of liquidity management has a positive impact on profitability, implying low liquidity and higher profitability (Jose et al., 1996). Financial decisions related to liquidity management are very important for banking operations and the impact they will have on banks' main goal to maximize profit. Liquidity management is an immediate need for the banking sector and banks need to set a level optimum solvency for solving this problem (Ibe, 2013).

\subsection{Bank Liquidity Concept}

Banking securitization means the bank's ability to meet its short-term liabilities (Kasmi, 2007, Van Ness, 2009). The term liquidity is multifaceted, the first and most important understanding of how quickly, costly and costly the bank's assets are invested in money (Berger \& Bouwmann, 2008). There is some theory of liquidity management: Shift-ability Theory-is an approach to keeping banks liquidity by supporting the shifting of assets. When a bank is short of ready money, it is able to sell assets to a more liquid bank. Under the shift-ability, the banking system strives to avoid liquidity crises by allowing banks to sell or repurchase at good prices (Alshatti, 2015). Liability management theory - there is no need to follow old liquidity norms such as maintaining liquid assets, liquid investments, banks have to focus on the liabilities side of the balance sheet. Banks can satisfy liquidity needs by borrowing money and capital markets (Emmanuel, NR, 1997). Different reports are used for the measurement of liquidity: Current ratio (CR) is expressed as the ratio of short-term assets to short-term liabilities and is one of the most used ratios for measuring liquidity (Czekaj \& Dresler 2001). Current assets are those that can be converted within one year to cash and current liabilities means an obligation that must fulfill within one year. The high values of this report show a high bank's ability to meet them. Cash ratio (CARR) - shows how much cash bank has to meet the short term requirements. CARR is expressed as a cash ratio with short-term liabilities. Interest coverage ratio or otherwise known as TIE interest earned ratio expressing the bank's ability to pay its interest cost on its debt. TIE is expressed as a ratio of interest and tax earning to total and cost interest over the same period. The Debt of Equity ratio is another important ratio calculated as a ratio between the total liabilities of the shareholder's equity. Debt of Equity ratio is negatively related to the ROA because when the Debt grows in the bank's capital structure, then the bank It also increases the weight of the cost of capital, the bank shrinking its lending policy, this leads to retail sales and thus reduces profitability. Capital ratio, which is calculated as a ratio of equity to the total of assets. Niresh (2012) in its study of the relationship between liquidity and profitability, I conclude that there was no relationship between the liquidity ratio measured by the capital ratio and the profitability measured with the Return on equity. Various studies related to the impact or reliability of profitability have found that their findings are mix (Note 1). The effect or the 
relationship between liquidity and profitability may be positive or negative depending on the variables used to measure liquidity or profitability (Rasul, 2013).

\subsection{Profitability}

Profitability is the ratio that shows the bank's ability to generate profit in relation to sales, total assets and equity (Sartono, 2001; Aburime, 2008). There are several ways to improve profitability, such as breakeven analysis, cost control, Ibe (2013). However, the main purpose of commercial banks is to maximize profits, but it is not easy to achieve because so many variables are concerned (Tosmocos, 2003). The bank's profitability is always measured by the ROE, ROA and ROCE ratios (Miller \& Bromily, 1990). ROA - Return on assets means how much profit the bank generated by asset management. ROA is calculated as the ratio between net profit and total assets. ROE - means the return earned in relation to the total invested capital. ROE is calculated as the ratio between net profit and total equity. ROCE is a profitability ratio that tells how a company is using its capital. ROCE Ratio is calculated as the ratio of Net Operating Income (EBIT) to the difference between (Total Assets - Current Liabilities). There are various dilemmas regarding the impact and level of liquidity in profitability. The liquidity ratio lower than 1 indicates that the bank has no liquid cash to repay the short-term debt (Morrel, 2007). The high liquidity ratio signals a situation of (Chandra, 2001), but for some other researchers, the high level of liquidity shows maladministration of the bank (Matarazzo, 2003). Hirigoyen (1985) in his study concludes that profitability and profitability are determinations of the banks equilibrated survival Both these factors are at the same time the result of the consequences and the restrictions.

\subsection{Research Ouestions}

To reach the conclusions of this study, the following research questions will be tested:

H1: Liquidity management and profitability are not related to each other?

H2: Banks with high-levels liquidity would be able to achieve a better performance?

H3: What is the optimum level of liquidity where we get a high level of profitability?

\section{Data and Methodology}

This study points out the relationship between liquidity management and profitability in the banking sector in Central and South Europe, using various reports for measuring liquidity and profitability. The liquidity ratio included in the study is Current ratio, Cash ratio, Capital ratio, Interest coverage ratio and Debt to Equity ratio while the measurement of profitability will be made by ROE, ROA and ROCE. Liquidity management is the independent variable in our model while profitability is the dependent variable. The data used in this study are collected from the consolidated annual reports of banks operating in Central and Southern Europe for the period 2009-2017. The data are analyzed in the Real Statistic Programme. The research model used is the following: 
Yit $=\alpha i+\beta 1 * X i t+\beta 2 * X i t+\beta 3 * X i t+\beta 4 * X i t+\beta 5 * X i t+\varepsilon i t$

Where:

Yit $=$ profitability, i refers to an individual bank, t refers to year, $\alpha=$ constant,

$\beta \mathrm{i}$ is the matrix of variable coefficients

$\varepsilon=$ Error term.

Three models were used in the study, where each model determines the effect of banks' profitability on liquidity management in Central and South Europe.

$\mathrm{ROE}=\alpha \mathrm{i}+\beta 1 * \mathrm{CR}_{\mathrm{it}}+\beta 2 * \mathrm{TIE}_{\mathrm{it}}+\beta 3 * \mathrm{CRR}_{\mathrm{it}}+\beta 4 *$ Capital ratio ${ }_{\text {it }}+\beta 5^{*}$ Debt Equity

ratio $_{i t}+\varepsilon_{\text {it }}$

$\mathrm{ROA}=\alpha \mathrm{i}+\beta 1 * \mathrm{CR}_{\mathrm{it}}+\beta 2 * \mathrm{TIE}_{\mathrm{it}}+\beta 3 * \mathrm{CRR}_{\mathrm{it}}+\beta 4 *$ Capital ratio it $+\beta 5^{*}$ Debt Equity ratio it $_{\text {it }}+$ cit

$\mathrm{ROCE}=\alpha \mathrm{i}+\beta 1 * \mathrm{CR}_{\mathrm{it}}+\beta 2 * \mathrm{TIE}_{\mathrm{it}}+\beta 3 * \mathrm{CRR}_{\mathrm{it}}+\beta 4 *$ Capital ratio $\mathrm{it}+\beta 5 *$ Debt Equity

ratio $_{i t}+\varepsilon_{\text {it }}$

Table 1. Determinants of Liquidity management and Banks profitability banks

\begin{tabular}{lll}
\hline Determinants & Variables & Measures \\
\hline & ROE & Net profit/Total Equity \\
ROA & Net profit/Total Assets \\
ROCE & EBIT/(Total Assets- Current Liability) \\
CR & Current Assets/Current Liability \\
& TIE & EBIT/Interest expensive \\
CRR & Cash/Current Liability \\
& Capital Ratio & Equity/ Total Assets \\
& Debt Equality Ratio & Total Liability/Equity \\
\hline
\end{tabular}

Source: Authors' assumptions.

\section{Data Analysis}

This study implements, describes, reports and econometric analysis in determining the effect of liquidity management on profitability in commercial banks in CEE (Central and Southern Europe) and the determination of the optimal level of liquidity over the time period (2009-2017), including analysis of profitability and liquidity indicators, regression analysis, correlation analysis, which are estimated by the OLS (Real Statistics) based on annual reports issued by commercial banks. 


\subsection{Statistical Analysis and Interpretation}

Table 2. Summary Statistic Southern Europa

\begin{tabular}{lllllllll}
\hline Variables & ROE & ROA & ROCE & CR & TIE & Cash ratio & $\begin{array}{l}\text { Capital } \\
\text { ratio }\end{array}$ & $\begin{array}{l}\text { Deb. Equity } \\
\text { ratio }\end{array}$ \\
\hline Mean & 0.046 & 0.006 & 0.048 & 1.178 & 0.847 & 0.187 & 0.152 & 6.955 \\
Median & 0.056 & 0.007 & 0.048 & 1.148 & 0.403 & 0.159 & 0.135 & 6.369 \\
St.Deviation & 0.153 & 0.022 & 0.135 & 0.210 & 2.599 & 0.144 & 0.082 & 3.637 \\
Kurtosis & 25.836 & 24.065 & 17.742 & 117.305 & 79.559 & 42.477 & 23.330 & 16.814 \\
Skewness & -3.664 & -2.789 & -1.144 & 7.969 & 7.281 & 4.812 & 3.591 & 2.572 \\
Maximum & 0.451 & 0.107 & 0.789 & 4.216 & 34.239 & 1.756 & 0.872 & 39.069 \\
Minimum & -1.324 & -0.184 & -1.008 & 0.136 & -5.387 & 0.000 & 0.025 & 0.334 \\
Count & 378 & 378 & 378 & 378 & 378 & 378 & 378 & 378 \\
\hline Shapiro - Wilk Test & & & & & & & 0.741 & 0.851 \\
W-stat & 0.690 & 0.683 & 0.738 & 0.517 & 0.451 & 0.686 & 0 & 0 \\
p-value & 0 & 0 & 0 & 0 & 0 & 0 & 0 & 0.05 \\
alpha & 0.05 & 0.05 & 0.05 & 0.05 & 0.05 & 0.05 & 0.05 & no \\
normal & no & no & no & no & no & no & no & \\
\hline d'Agostino - Pearson & & & & & & & \\
\hline DA-stat & 339.44 & 286.46 & 160.92 & 582.41 & 544.05 & 418.29 & 330.89 & 256.698 \\
p-value & 0 & 0 & 0 & 0 & 0 & 0 & 0 & 0 \\
alpha & 0.05 & 0.05 & 0.05 & 0.05 & 0.05 & 0.05 & 0.05 & 0.05 \\
normal & no & no & no & no & no & no & no & no \\
\hline Source: Aunt & & & & & &
\end{tabular}

Source: Authors' calculations.

Table 3. Summary Statistic Central Europa

\begin{tabular}{lllllllll}
\hline & ROE & ROA & ROCE & CR & TIE & Cash ratio & Capital ratio & Deb. Equity ratio \\
\hline Mean & 0.0185 & 0.0032 & 0.0323 & 1.7091 & 1.6190 & 0.1365 & 0.1015 & 10.0678 \\
Median & 0.0390 & 0.0038 & 0.0367 & 1.1100 & 0.3141 & 0.0731 & 0.0980 & 9.2085 \\
Standard & & & & & & & & \\
Deviation & 0.2028 & 0.0174 & 0.1368 & 2.4612 & 12.9814 & 0.5436 & 0.0348 & 4.3226 \\
Kurtosis & 25.0707 & 42.9044 & 25.377 & 12.862 & 212.444 & 209.739 & 3.2844 & 9.7309 \\
Skewness & -4.1876 & -5.0175 & -4.0705 & 3.8277 & 14.3771 & 14.2486 & 1.2721 & 2.3517 \\
Maximum & 0.5631 & 0.0594 & 0.3292 & 13.219 & 192.747 & 8.1144 & 0.2497 & 38.2159 \\
Minimum & -1.4449 & -0.1621 & -1.0261 & 0.1075 & -7.9348 & 0.0000 & 0.0255 & 3.0043 \\
Count & 225 & 225 & 225 & 225 & 225 & 225 & 225 & 225 \\
\hline Shapiro - Wilk Test & & & & & & & \\
\hline W-stat & 0.598 & 0.597 & 0.661 & 0.276 & 0.113 & 0.126 & 0.919 & 0.824 \\
p-value & 0 & 0 & 0 & 0 & 0 & 0 & $9.73881 \mathrm{E}-102.88658 \mathrm{E}-15$ \\
alpha & 0.05 & 0.05 & 0.05 & 0.05 & 0.05 & 0.05 & 0.05 & 0.05 \\
normal & no & no & no & no & no & no & no & no \\
\hline d'Agostino - Pearson & & & & & & & \\
\hline DA-stat & 231.521 & 272.005 & 228.199 & 199.668 & 494.330 & 492.227 & 62.984 & 137.617 \\
p-value & 0 & 0 & 0 & 0 & 0 & 0 & $2.10942 \mathrm{E}-$ & 0 \\
alpha & 0.05 & 0.05 & 0.05 & 0.05 & 0.05 & 0.05 & 0.05 & 0.05 \\
normal & no & no & no & no & no & no & no & no \\
\hline Source: Aun
\end{tabular}

Source: Authors' calculations.

Table 2 shows the results of all variables included in the three models for banks operating in south Europe. The results show that the ROE has an average value of 0.046, which indicates 
that the value the average return on equity for banks is $4.6 \%$. The value of the standard deviation for ROE is 0.153 . Regarding the control variables used to measure the independent liquidity variable, the results of the study show that CRR has an average value of 0.1871 and a standard deviation value of 0.144 . The average value of the TIE variable is 0.847 and the standard deviation value is 2.599 , which indicates that the bank presents less risk to investors and creditors in terms of solvency. So from this point of view, banks are considered as banks with acceptable risk. The mean values and the standard deviation for the $\mathrm{CR}$ variable are 1.178 and 0.2102 . This shows that the bank has easy to repay its debts. The results of table 2 show that the values of capital ratio are 0.1522 for the average and 0.082 standard deviation and the debt equity ratio deviation standard is 3.6373 and 6.955 average values. The average ROA value for banks is 0.006 and the standard deviation value is 0.022 . Also in the study is used another variable to measure ROCE profit, where the value of the standard deviation 0.048 and the value of the average 0.135 . Table 3 shows the results of the banks operating in the Central Europe, the ROE has an average value of 0.019 , which indicates that the value the average return on equity for banks is $1.9 \%$, so $2.7 \%$ less than the average return on equity for banks operating in south Europe. The standard deviation value for ROE is 0.203 . The average ROA value for banks is 0.003 and the standard deviation value is 0.017 . For the other ROCE variable, the value of the standard deviation 0.14 and the mean value of 0.032 . Regarding the control variables used to measure the independent liquidity variable, the results of the study show that CRR has an average value of 0.14 and a standard deviation value of 0.544 . The average value of the TIE variable is 1.62 and the standard deviation value is 12.98 , mean values and standard deviation for the $\mathrm{CR}$ variable are 1.71 and 2.46. From the results of Table 3 , it is shown that the values of the explanatory variables capital ratios are 0.101 for the average value and 0.035 standard deviation, and the debt equity ratio deviation standard is 10.07 and 4.322 average values. The Kurtosis and Skewness values show that the data used in the analysis are not normally distributed. Also, two tests were used to verify the normality of the data: a) Anderson Darling test and b) Shapiro-Wilk test. The hypotheses in this case are:

H0: The data are normally distributed

H1: The data are not normally distributed

The condition for the Anderson Darling test is: If, P-value> alpha, we keep the null hypothesis and reject the alternative hypothesis. Based on the results of tables 2 and 3, all variables included in the study have abnormal distribution because P-values are less than alpha 005 .

The condition for the Shapiro Wilk test is: If, P- value $<$ alpha at level 0.05 , we reject the null hypothesis. The results of tables 2 and 3 confirm that the data have abnormal distribution. Based on the results of the two tests Shapiro-Wilk and Anderson Darling use non-parametric test for further data analysis. To test whether time series of explanatory variables and dependent variables are stationary or not, we applied the Kwiatkowski-Phillips-Schmidt-Shin (KPSS) test to see the existence of a network unit. 
$\mathrm{H} 0$ : The series is stationary.

H1: There is a unit root. The series is not stationary.

Table 4. Results of KPSS

\begin{tabular}{lllll}
\hline & Southern Europa & & Central Europa & \\
\hline Variables & KPSS-statistic & P-value & KPSS-statistic & P-value \\
ROE & 3.987 & 0.06 & 2.187 & 0.11 \\
CR & 4.856 & 0.11 & 5.089 & 0.08 \\
TIE & 2.098 & 0.1 & 3.132 & 0.13 \\
CRR & 6.345 & 0.07 & 4.089 & 0.09 \\
Capital ratio & 7.654 & 0.09 & 5.324 & 0.1 \\
Deb equity ratio & 3.056 & 0.077 & 3.932 & 0.22 \\
Variables & KPSS-statistic & P-value & KPSS-statistic & P-value \\
ROA & 5.345 & 0.09 & 4.123 & 0.21 \\
CR & 3.645 & 0.13 & 3.046 & 0.07 \\
TIE & 5.534 & 0.07 & 1.934 & 0.23 \\
CRR & 6.089 & 0.1 & 3.254 & 0.15 \\
Capital ratio & 8.675 & 0.12 & 6.453 & 0.09 \\
Deb equity ratio & 4.321 & 0.056 & 2.191 & 0.06 \\
Variables & KPSS-statistic & P-value & KPSS-statistic & P-value \\
ROCE & 6.587 & 0.075 & 2.089 & 0.12 \\
CR & 3.756 & 0.17 & 4.043 & 0.07 \\
TIE & 1.798 & 0.08 & 2.098 & 0.17 \\
CRR & 5.345 & 0.09 & 3.203 & 0.21 \\
Capital ratio & 4.067 & 0.095 & 4.324 & 0.41 \\
Deb equity ratio & 3.083 & 0.067 & 5.423 & 0.06 \\
\hline
\end{tabular}

Source: Authors' calculations.

The results of Table 4 show that P-value values for explanatory and dependent variables for banks operating in CEE(Central East Europa, include these countries: Albania, Kosovo, Nord Macedonia, Montenegro, Bulgaria, Serbia, Bosnia Herzegovina, Croatia, Romania, Slovenia, Slovakia, Czech) are higher than the significance level alpha 0.05, so we should keep the null hypothesis $\mathrm{H} 0$ and reject the alternative hypothesis. So the series is stationary and there is no unit root for the series.

\subsection{Correlation Analysis}

To analyze the correlation test, we need to examine the correlation between dependent variables and independent variables. For this we have two hypotheses:

H0: There is no correlation between liquidity management and banks profitability.

H1: There is a correlation between liquidity management and bank profitability 
Table 5. Model 1, ROE-Correlation analysis

\begin{tabular}{|c|c|c|c|c|c|c|}
\hline & & & & Cash & Capital & Deb equity \\
\hline South Europa & $\mathrm{ROE}$ & $\mathrm{CR}$ & TIE & ratio & ratio & ratio \\
\hline $\mathrm{ROE}$ & 1.000 & & & & & \\
\hline CR & 0.162 & 1.000 & & & & \\
\hline TIE & 0.823 & 0.270 & 1.000 & & & \\
\hline CRR & 0.150 & 0.270 & 0.170 & 1.000 & & \\
\hline Capital ratio & 0.037 & 0.590 & 0.220 & 0.140 & 1.000 & \\
\hline Debt equity ratio & -0.037 & -0.590 & -0.220 & -0.140 & -0.450 & 1.000 \\
\hline \multicolumn{7}{|c|}{ Spearman coefficients } \\
\hline Rho & & 0.162 & 0.822 & 0.158 & 0.037 & -0.037 \\
\hline T-stat & & 2.457 & 21.582 & 2.384 & 0.554 & -0.556 \\
\hline P-value & & 0.070 & 0.000 & 0.017 & 0.570 & -0.578 \\
\hline \multicolumn{7}{|c|}{ Kendall's coefficients } \\
\hline Z & & 2.520 & 14.374 & 2.359 & 0.624 & -0.627 \\
\hline Z-crit & & 1.950 & 1.959 & 1.959 & 1.959 & 1.959 \\
\hline \multirow[t]{2}{*}{ P-value } & & 0.011 & 0.000 & 0.018 & 0.530 & 0.530 \\
\hline & & & & & Capital & Debt equity \\
\hline Central Europa & ROE & CR & TIE & CRR & ratio & ratio \\
\hline ROE & 1.000 & & & & & \\
\hline $\mathrm{RC}$ & 0.053 & 1.000 & & & & \\
\hline TIE & 0.085 & -0.016 & 1.000 & & & \\
\hline CRR & 0.039 & 0.305 & -0.006 & 1.000 & & \\
\hline Capital ratio & 0.050 & 0.013 & 0.101 & -0.116 & 1.000 & \\
\hline Debt equity ratio & -0.009 & -0.011 & -0.085 & 0.236 & -0.826 & 1.000 \\
\hline \multicolumn{7}{|c|}{ Spearman coefficients } \\
\hline Rho & & 0.157 & 0.822 & 0.153 & 0.037 & -0.037 \\
\hline T-stat & & 2.388 & 21.568 & 2.323 & 0.561 & -0.562 \\
\hline$\underline{P \text {-value }}$ & & 0.017 & 0.000 & 0.021 & 0.575 & 0.574 \\
\hline \multicolumn{7}{|c|}{ Kendall's coefficients } \\
\hline $\mathrm{Z}$ & & 2.457 & 14.396 & 2.299 & 0.623 & -0.627 \\
\hline Z-crit & & 1.959 & 1.959 & 1.959 & 1.959 & 1.959 \\
\hline P-value & & 0.013 & 0 & 0.021 & 0.532 & 0.53 \\
\hline
\end{tabular}

Source: Authors' calculations.

From Table 5 we see that the correlation between CRR and ROE is very weak and positive, while the TIE variable has a strong correlation with ROE in the value of 0.823 . On the other hand, the CR variable has a weak and positive correlation with ROE. So we can say that the two CRR and CR variables have a non-zero correlation with the dependent ROE variables. Spearman and Kendall's Tau test scores, used to test the hypothesis:

H0: The variables are not correlated.

H1: The variables are correlated.

The decision rule as follow:

Accept $\mathrm{H} 0$ if $(\mathrm{P}-$ value $)>5 \%$

Accept Ha if (P-value) $<5 \%$

The analysis outputs show that among the dependent variables ROE and independent 
variables CR, TIE and CRR, there is a statistically significant difference or relationship between them. As long as the values of P-value (0.014 (0.0172); $0(0) ; 0.018)$ are smaller than 0.05 and $\mathrm{Z}$ values are greater than the values of $\mathrm{Z}$ critics, between the variables has a relationship. While the Capital ratio and the debt ratio do not have a correlation with ROE, since the P-values values are greater than 0.05 so I can not reject the null hypothesis. Also the TIE variable is correlated positively and has a strong relation $r(0.823)$ with ROE. In Banks operating in Central European countries, the variables CR, TIE and CRR are positive and weak links with the ROE. Two dependent variables Capital ratio and Debt ratio have no correlation or correlation with ROE.

Table 6. Model 2, ROA - Correlation Analysis

\begin{tabular}{|c|c|c|c|c|c|c|}
\hline & & & & Cash & Capital & Deb equity \\
\hline South Europa & ROA & $\mathrm{CR}$ & TIE & ratio & ratio & ratio \\
\hline $\mathrm{ROA}$ & 1.000 & & & & & \\
\hline $\mathrm{CR}$ & 0.252 & 1.000 & & & & \\
\hline TIE & 0.830 & 0.270 & 1.000 & & & \\
\hline CRR & 0.220 & 0.270 & 0.170 & 1.000 & & \\
\hline Capital ratio & 0.205 & 0.590 & 0.220 & 0.140 & 1.000 & \\
\hline Debt equity ratio & -0.205 & -0.590 & -0.220 & -0.140 & -0.450 & 1.000 \\
\hline \multicolumn{7}{|c|}{ Spearman coefficients } \\
\hline Rho & & 0.251 & 0.870 & 0.226 & 0.205 & -0.205 \\
\hline T-stat & & 3.873 & 26.310 & 3.459 & 3.126 & -3.127 \\
\hline P-value & & 0.000 & 0.000 & 0.000 & 0.002 & 0.001 \\
\hline \multicolumn{7}{|c|}{ Kendall's coefficients } \\
\hline $\mathrm{Z}$ & & 3.958 & 15.758 & 3.251 & 3.178 & -3.182 \\
\hline Z-crit & & 1.959 & 1.959 & 1.959 & 1.959 & 1.959 \\
\hline & & 7.55E- & & & & \\
\hline \multirow[t]{2}{*}{$\underline{\text { P-value }}$} & & 03 & 0.000 & 0.001 & 0.001 & 0.001 \\
\hline & & & & & Capital & Deb equity \\
\hline Central Europa & $\mathrm{ROA}$ & $\mathrm{CR}$ & TIE & CRR & ratio & ratio \\
\hline $\mathrm{ROA}$ & 1.000 & & & & & \\
\hline $\mathrm{CR}$ & 0.041 & 1.000 & & & & \\
\hline TIE & 0.100 & -0.016 & 1.000 & & & \\
\hline CRR & 0.025 & 0.305 & -0.006 & 1.000 & & \\
\hline Capital ratio & 0.134 & 0.013 & 0.101 & -0.116 & 1.000 & \\
\hline Deb equity ratio & -0.093 & -0.011 & -0.085 & 0.236 & -0.826 & 1.000 \\
\hline \multicolumn{7}{|c|}{ Spearman coefficients } \\
\hline Rho & & 0.245 & 0.87 & 0.1061 & 0.206 & -0.206 \\
\hline T-stat & & 3.787 & 26.349 & 1.594 & 3.148 & -3.149 \\
\hline $\mathrm{P}$-value & & 0.0001 & 0 & 0.114 & 0.0018 & 0.001 \\
\hline \multicolumn{7}{|c|}{ Kendall's coefficients } \\
\hline $\mathrm{Z}$ & & 3.869 & 15.797 & 1.61 & 3.194 & -3.198 \\
\hline Z-crit & & 1.959 & 1.959 & 1.959 & 1.959 & 1.959 \\
\hline P-value & & 0.0001 & 0 & 0.1 & 0.0013 & 0.0013 \\
\hline
\end{tabular}

Source: Authors' calculations.

The results of the correlation analysis for the second model for banks in south Europe show that the variables have a weak and positive relationship with the ROA dependent variables. 
While the Debt equity ratio has a negative relationship with ROA, only the TIE variable indicates a strong bond with ROA. Also, the P-value and $\mathrm{Z}$ values of the Spearman and Kendall Tau tests cast down the null hypothesis, showing that between independent variables and the dependent variables ROA, there is a statistically significant difference or relationship between them.For the model of banks in Central Europe notes that there is a positive, but weak, relationship between CR, TIE and Capital ratios with ROA, while the Debt equity ratio has a negative relationship and is still weak with ROA. The CRR and ROA variables are not correlated, as the test results Spearman and Kendall show that the value P-value (0.112) of the variable is greater than 0.05 .

Table 7. Model 3 ROCE_Correlation Analysis

\begin{tabular}{|c|c|c|c|c|c|c|}
\hline & & & & Cash & Capital & $\begin{array}{l}\text { Deb } \\
\text { equity }\end{array}$ \\
\hline South Europa & ROCE & $\mathrm{CR}$ & TIE & ratio & ratio & ratio \\
\hline ROCE & 1.000 & & & & & \\
\hline $\mathrm{CR}$ & 0.073 & 1.000 & & & & \\
\hline TIE & 0.834 & 0.270 & 1.000 & & & \\
\hline CRR & 0.110 & 0.270 & 0.170 & 1.000 & & \\
\hline Capital ratio & 0.040 & 0.590 & 0.220 & 0.140 & 1.000 & \\
\hline Debt equity ratio & -0.040 & -0.590 & -0.220 & -0.140 & -0.450 & 1.000 \\
\hline \multicolumn{7}{|c|}{ Spearman coefficients } \\
\hline Rho & & 0.073 & 0.834 & 0.110 & 0.034 & -0.034 \\
\hline T-stat & & 1.095 & 22.565 & 1.660 & 0.511 & -0.512 \\
\hline P-value & & 0.274 & 0.000 & 0.098 & 0.608 & 0.608 \\
\hline \multicolumn{7}{|c|}{ Kendall's coefficients } \\
\hline $\bar{Z}$ & & 0.973 & 14.783 & 1.680 & 0.561 & -0.561 \\
\hline Z-crit & & 1.959 & 1.959 & 1.959 & 1.959 & 1.959 \\
\hline \multirow[t]{2}{*}{ P-value } & & 0.330 & 0.000 & 0.092 & 0.574 & 0.574 \\
\hline & & & & Cash & Capital & $\begin{array}{l}\text { Deb } \\
\text { equity }\end{array}$ \\
\hline Central Europa & ROE & $\mathrm{CR}$ & TIE & ratio & ratio & ratio \\
\hline ROCE & 1.000 & & & & & \\
\hline $\mathrm{CR}$ & -0.022 & 1.000 & & & & \\
\hline TIE & 0.095 & -0.016 & 1.000 & & & \\
\hline CRR & 0.002 & 0.305 & -0.006 & 1.000 & & \\
\hline Capital ratio & -0.006 & 0.013 & 0.101 & -0.116 & 1.000 & \\
\hline Debt equity ratio & 0.008 & -0.011 & -0.085 & 0.236 & -0.826 & 1.000 \\
\hline \multicolumn{7}{|c|}{ Spearman coefficients } \\
\hline Rho & & 0.067 & 0.833 & 0.106 & 0.035 & -0.035 \\
\hline T-stat & & 1.014 & 22.518 & 1.594 & 0.523 & -0.525 \\
\hline P-value & & 0.311 & 0.000 & 0.112 & 0.600 & 0.600 \\
\hline \multicolumn{7}{|c|}{ Kendall's coefficients } \\
\hline $\mathrm{Z}$ & & 0.900 & 14.791 & 1.610 & 0.568 & -0.568 \\
\hline Z-crit & & 1.959 & 1.959 & 1.959 & 1.959 & 1.959 \\
\hline P-value & & 0.368 & 0.000 & 0.107 & 0.569 & 0.569 \\
\hline
\end{tabular}

Source: Authors' calculations. 


\section{Ml Macrothink}

International Finance and Banking

ISSN 2374-2089

2019, Vol. 6, No. 2

From the results of Table 7, we note that there is a positive and strong correlation between ROCE and TIE with the value $\mathrm{r}(0.834)$ while for the other independent variables P-values are greater than 0.05 can not reject the hypothesis null, there is no relationship between the variables. Also for the model in the Central Europa banks, only the TIE variable has a positive and weak relation with ROE with $r$ value $(0.095)$, while the other variables are not related to the variable dependent ROCE. This is supported by the results of P-values greater than 0.05

\subsection{Regression Analysis}

Table 8. Model 1: Model Summary and Kruskal- Wallis H Test (Dependent Variable: ROE for 2009-2017)

\begin{tabular}{lllll}
\hline Variables & Coefficients & & \\
\hline South Europa & Std. & & \\
\hline Constant & B & Error & T-value & Significance \\
CR & 0.18643256 & 0.05698231 & 3.27176215 & 0.00116871 \\
TIE & -0.09099347 & 0.05125244 & -1.77539796 & 0.04765744 \\
CRR & 0.02228006 & 0.00283397 & 7.8617937 & $4.1348 \mathrm{E}-14$ \\
Capital ratio & -0.08469119 & 0.05948199 & -1.42381237 & 0.00345634 \\
Debt Equity ratio & -0.05085124 & 0.15447032 & -0.32919751 & 0.11296754 \\
\hline & -0.00415975 & 0.00290429 & -1.43228001 & 0.15290343 \\
\hline Multiple R & & R & & \\
Adjusted R Square & 0.40818504 & Square & 0.16661503 & P-value \\
Durbin-Watson Stat & 0.15541362 & $\mathrm{H}$ & 1659.25 & 0 \\
\hline
\end{tabular}

Source: Authors' calculations.

The regression results in Table 8 show that the value of R Square is 0.166 means that $17 \%$ of the variance of the dependent ROE variables can be explained by independent variables. Table 8 shows that the value of the statistical $\mathrm{H}$ is 1659.25 and the value of the P-value $2.582 \mathrm{E}-13$, which is less than 0.05 , this means that the regression equation is significant and can be used to predict the relationship between the dependent and the independent variables. Looking $\mathrm{p}$ values for each independent variable, TIE, CR and CRR are less than alpha (0.05), so we reject the invalid hypothesis and we can say that these variables affect ROE. The value of $\mathrm{p}$ for Capital ratio variable and Debt equity ratio variable is greater than 0.05 , so we can not reject the invalid hypothesis that there is no correlation and can not say that they affect ROE.

The regression equation for the model is:

$\mathrm{y}=-0.186-0.091 * \mathrm{CR}+0.022 * \mathrm{TIE}-0.084 * \mathrm{CRR}$ 


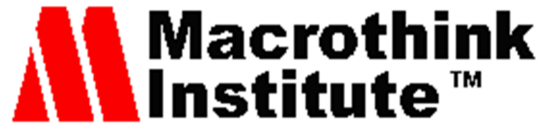

Table 9. Model 2: Model Summary and Kruskal-Wallis H Test (Dependent Variable: ROA for 2009-2017)

\begin{tabular}{lllll}
\hline Variables & Coefficients & & & \\
\hline South Europa & Std. & T-value & Significance \\
\hline Constant & B & Error & 9.16236945 & $3.4784 \mathrm{E}-18$ \\
CR & 0.06791215 & 0.00741207 & -6.35131056 & $6.2324 \mathrm{E}-10$ \\
TIE & -0.0423426 & 0.00666675 & 8.68685959 & $1.1961 \mathrm{E}-16$ \\
CRR & 0.00320226 & 0.00036863 & -3.56226296 & 0.00041546 \\
Capital ratio & -0.02756202 & 0.00773722 & -0.01391311 & 0.00476786 \\
Debt Equity ratio & -0.00027956 & 0.020093 & -3.45980589 & 0.00060325 \\
\hline Multiple R & -0.00130705 & 0.00037778 & 0.34067 & p-value \\
Adjusted R Square & 0.5836 & R Square & 1811.54 & 0 \\
Durbin-Watson Stat & 0.3318 & H & & \\
\hline
\end{tabular}

Source: Authors' calculations.

The P- value a Kruskal-Wallis $\mathrm{H}$ test, which measures the common significance of the explanatory variables, is statistically significant at the 5\% level, according to the respective probability value of 0.000 . So it shows that the model used is suitable. The results of Table 9 show that the CR coefficient is negative and statistically significant at 5\% with a probability of $6.2324 \mathrm{E}-10$. The regression analysis shows that the probability of the TIE coefficient is 0.003 and is statistically significant at the 5\% level. Keeping of all the other constant coefficients, an increase of 1 unit in the TIE variable will lead to an increase in the ROA variable with 0.003 units. The results show that the CRR coefficient is statistically significant at the $5 \%$ level with a probability of 0.0041 and implies a negative correlation between the variables. Keeping constant coefficients, a 1-unit increase in the CRR variable will lead to a decrease in the ROA variance of 0.0027 units. Capital ratio variable is lower than $5 \%$, and has a negative relationship with ROA. The value of the P-value for the variable Debt equity ratio is lower than 5\% and there is a negative relationship between ROA and R2 corrected 0.332 so it suggests that $33.2 \%$ of total ROA variation in commercial banks in southern Europe is explained by variations common in independent variables. The model equation in this case is:

$\mathrm{y}=-0.068-0.042 * \mathrm{CR}+0.003 *$ TIE $-0.0027 *$ CRR-0,0002*Capital ratio $-0.001 *$ Debt equity ratio 


\section{Ml Macrothink}

Table 10. Model 3: Model Summary and Kruskal-Wallis H Test (Dependent Variable: ROCE for 2009-2017)

\begin{tabular}{lllll}
\hline Variables & Coefficients & & & \\
\hline South Europa & $\mathrm{B}$ & Std. Error & P-value & Significance \\
\hline Constant & 0.057879518 & 0.049557471 & 1.167927195 & 0.243584124 \\
& - & & - & \\
CR & 0.010592562 & 0.044574206 & 0.237638822 & 0.50334445 \\
TIE & 0.021035499 & 0.002464699 & 8.534713699 & $3.61726 \mathrm{E}-16$ \\
CRR & 0.015117644 & 0.051731439 & 0.292233196 & 0.60234321 \\
Capital ratio & 0.038805902 & 0.134342717 & 0.288857504 & 0.772851323 \\
& - & & - & \\
Debt Equity ratio & 0.003480918 & 0.002525855 & 1.378114774 & 0.168996189 \\
\hline Multiple R & 0.4317 & $\mathrm{R} \mathrm{Square}$ & 0.1864 & $\mathrm{p}$-value \\
Adjusted R & & & & 0 \\
Square & 0.1754 & $\mathrm{H}$ & & 0 \\
Durbin-Watson & & & & \\
Stat & 1.55269482 & & & \\
\hline
\end{tabular}

Source: Authors' calculations.

The regression results in Table 10 show that the value of Square $\mathrm{R}$ is 0.186 means that $19 \%$ of the variance of the dependent ROCE variables can be explained by independent variables. The value of P-value, which measures the common significance of the explanatory variables, is statistically significant at the $5 \%$ level, according to the respective probability value of 0,000 . So this shows that the model used is appropriate and the model equation is:

$\mathrm{y}=-0.0578+0.00210 * \mathrm{TIE}$

The results of Table 10 show that the TIE variable P-value is 3,61726E-16 and is statistically significant at $5 \%$ level and the relation between them is positive.Keeping all the other constant coefficients, an increase of 1 unit in the TIE variable will lead to an increase in the ROCE variable of 0.0210 units. The results show that all other variables have no connection or impact on ROCE.

Models for Banks in Central Europe. 
Table 11. Model 1: Model Summary and Kruskal-Wallis H Test (Dependent Variable: ROE for 2009-2017)

\begin{tabular}{|c|c|c|c|c|}
\hline Variables & Coefficients & & & \\
\hline Central Europa & $\mathrm{B}$ & $\begin{array}{l}\text { Std. } \\
\text { Error }\end{array}$ & T-value & \\
\hline Constant & 30.04534555 & 0.108254693 & 0.124618306 & -0.8686901 \\
\hline $\mathrm{CR}$ & 0.004014489 & 0.005831585 & 0.688404556 & 0.00067654 \\
\hline TIE & 0.001281485 & 0.001053219 & 1.216731582 & 0.00756545 \\
\hline CRR & 0.006169638 & 0.027449368 & 0.22476432 & 0.00234565 \\
\hline Capital ratio & 0.709399776 & 0.701250841 & 1.011620571 & 0.78045345 \\
\hline \multirow[t]{2}{*}{ Debt Equity ratio } & 0.004467802 & 0.005781956 & 0.772714601 & 0.44052445 \\
\hline & & $\mathrm{R}$ & & p-value \\
\hline Multiple R & 0.687 & Square & 0.107 & \\
\hline Adjusted R Square & 0.087 & $\mathrm{H}$ & 913.139 & 0 \\
\hline Durbin-Watson & & & & \\
\hline Stat & 1.15528725 & & & \\
\hline
\end{tabular}

Source: Authors' calculations.

Table 12. Model 2: Model Summary and Kruskal-Wallis H Test (Dependent Variable: ROA for 2009-2017)

\begin{tabular}{lllll}
\hline Variables & Ceofficients & & & \\
\hline Central Europa & $\mathrm{B}$ & Std. Error & T-value & Sig. \\
\hline Constant & 0.007851896 & 0.010607984 & 0.740187408 & 0.04657877 \\
CR & 0.000236372 & 0.000496407 & 0.476166282 & 0.00209899 \\
TIE & 0.000117735 & $8.9654 \mathrm{E}-05$ & 1.313212911 & 0.00009878 \\
CRR & 0.000738154 & 0.002336595 & 0.315909962 & 0.752371716 \\
Capital ratio & 0.083229081 & 0.05969314 & 1.394282176 & 0.00012111 \\
Debt Equity ratio & 0.000189509 & 0.000492182 & 0.385038395 & 0.00065655 \\
\hline & & $\mathrm{R}$ & & $\mathrm{p}$-value \\
\hline Multiple R & 0.6208 & $\mathrm{R}$ Square & 0.102 & P-value \\
Adjusted R Square & 0.0819 & $\mathrm{H}$ & 1023.7 & 0 \\
Durbin-Watson Stat & 1.19935858 & & & \\
\hline
\end{tabular}

Source: Authors' calculations.

Table 13. Model 3: Model Summary and Kruskal-Wallis H Test (Dependent Variable: ROCE for 2009-2017)

\begin{tabular}{lllll}
\hline Variables & Coefficients & & & \\
\hline Central Europa & $\mathrm{B}$ & Std. Error & T-value & Significance \\
\hline Constant & 0.032983391 & 0.084318691 & 0.391175324 & 0.00785777 \\
CR & -0.001266825 & 0.003945741 & -0.321061236 & 0.70012111 \\
TIE & 0.001018216 & 0.000712625 & 1.428825135 & 0.00768767 \\
CRR & 0.001740868 & 0.01857267 & 0.093732795 & 0.11978677 \\
Capital ratio & -0.030635543 & 0.474477261 & -0.064566935 & 0.948577709 \\
Debt Equity ratio & 0.000265439 & 0.003912162 & 0.067849736 & 0.65234978 \\
\hline Multiple R & 0.9989 & R Square & 0.2097 & p-value \\
Adjusted R Square & 0.1916 & $\mathrm{H}$ & 916.967 & 0 \\
Durbin-Watson Stat & 1.09964878 & & & \\
\hline Source: Auts & & &
\end{tabular}

Source: Authors' calculations. 


\section{Ml Macrothink}

International Finance and Banking

ISSN 2374-2089

2019, Vol. 6, No. 2

Drawing on the values of the coefficients determined in the tables $11,12,13$, below are the equations of the respective models:

$\mathrm{Y}=-0.1082+0.004 * \mathrm{CR}+0.0012 * \mathrm{TIE}+0.0061 * \mathrm{CRR} \quad(\mathrm{ROE})$

$\mathrm{Y}=-0.0079+0.0023 * \mathrm{CR}+0.00011 * \mathrm{TIE}+0.0832 *$ Capital ratio $+0.0018 *$

Debt equity ratio $(\mathrm{ROA})$

$\mathrm{Y}=0.0329+0.0010 *$ TIE $\quad(\mathrm{ROCE})$

In the first equation (ROE) is positively influenced by CR, CRR, and TIE, while the other two variables Capital ratio, and Debt equity ratio have no effect on the profitability of banks in central Europe.In the equation where ROA is used to measure profitability, the specific variables CR, TIE, Capital ratio and debt equity ratio are positively with profitability. Keeping all the other constant factors an increase from a unit in CR, TIE, Capital ratio, the Debt ratio will result in an increase in profitability (ROA) of 0.00023 units of CR, 0.00011 units of TIE, 0.0832 units of Capital ratio and 0.00018 units of Debt equity ratio. In the model when ROCE is used to measure the profitability, the variable TIE has a positive effect on profitability.

\section{Hypothesis Two: Banks with High Level Liquidity Would be Able to Achieve A Better Performance?}

Over the year of 2017 the banks with higher liquidity would be able to achieve a better performance. To test the hypothesis we group banks into two large groups according to their CR ratio in analysis period 2017 :

(A) banks with CR ratio higher than 1,1 (Banks with high liquidity)

(B) Banks with CR ratio lower than 1,1 (Banks with low liquidity)

The respective statistical data for both groups are presented in Table 14:

Table 14. Descriptive statistic

\begin{tabular}{|c|c|c|c|c|c|c|}
\hline & $\begin{array}{l}\text { Central } \\
\text { Europa } \\
\text { Banks } \\
\end{array}$ & & & South Europa & 3anks & \\
\hline & High & Low & & High & Low & \\
\hline & $\begin{array}{l}\text { Liquidity } \\
\text { (A) }\end{array}$ & $\begin{array}{l}\text { Liquidity } \\
\text { (B) }\end{array}$ & Total & $\begin{array}{l}\text { Liquidity } \\
\text { (A) }\end{array}$ & $\begin{array}{l}\text { Liquidity } \\
\text { (B) }\end{array}$ & Total \\
\hline Mean & 1.144015749 & 1.077168161 & 1.128008113 & 1.211280821 & 0.997698247 & 1.158998694 \\
\hline Median & 1.124021236 & 1.073357997 & 1.111037792 & 1.178655442 & 1.043735872 & 1.142861285 \\
\hline Standard & & & & & & \\
\hline Deviation & 0.051725921 & 0.010540278 & 0.053004006 & 0.111260629 & 0.159478149 & 0.148783806 \\
\hline Maximum & 1.280999945 & 1.088656823 & 1.280999945 & 1.610546449 & 1.090886247 & 1.610546449 \\
\hline Minimum & 1.095039227 & 1.066107665 & 1.066107665 & 1.106099399 & 0.580854766 & 0.580854766 \\
\hline Count & 19 & 6 & 25 & 31 & 11 & 42 \\
\hline $\mathrm{ROA}>0$ & 19 & 6 & 25 & 29 & 10 & 39 \\
\hline $\mathrm{ROA}<0$ & 0 & 0 & 0 & 2 & 1 & 3 \\
\hline
\end{tabular}

Source: Authors' calculations. 
There are 31 banks (74\%) and banks (A) for the banks in southern Europe (11\%), while in the group (B) there are 11 banks (26\%), while in the Central Bank there are 19 banks (76\%) and in group (B) 6 banks (24\%), in order to reach the hypothesis we will compare ROA for both groups from the average and the average statistical values we can observe that the high liquidity (A) banks in South Europe and Central Europe do not have any major changes with low liquidity (B) banks, but the difference between the averages ( 0.213582574$)$ and medians (0.13491957) for banks operating in south Europe is higher than the difference between the averages (0.07) and the medians (0.05) for the banks in Central Europe. In the high liquidity group (A) for Southern Europe there is only 1 bank (6\%) and for the same group, but in Central Europe there is no bank showing losses for 2017, while in group (B) with liquidity there are 3 banks $(9 \%)$ for southern Europe that have a negative income while for banks in central Europe there is no bank with negative performance. This shows that there is no distinction between high liquidity banks with low liquidity banks operating in CEE. For the true measure of whether there are changes we will test the hypothesis:

H0: The average ROA for both groups is the same

H1: ROA for group (A) is higher than group (B),

$\mathrm{H} 0: \mu \mathrm{a}=\mu \mathrm{bH} 1: \mu \mathrm{a}>\mu \mathrm{b}$

Since the data have abnormal distribution, to prove the hypothesis use The Mann-Whitney U test for nonparametric data. The results of the Mann - Whintey Test show that $\mathrm{z}$ can now be checked for relevance by comparing it to the critical standard distribution standard (z-distribution) value.This critical value can be obtained from the table. For the level of meaning of two sides, 0.50 is \pm 1.96 . If the amount of test statistic is higher than the critical value, the difference is significant. On our own, the banks operating in southern Europe (| $0.976 \mid<1.96)$. and those in central Europe have $(|1.78|<1.96)$. Therefore, we can say that the two trends do not change (exactly the Mann-Whitney $U$ test for the south Europa banks: $U=150, p=0.33>0.05$ and the Mann-Whitney $U$ test for a bank in central Europe: $U=29, p$ $=0.074>0.05$ ). So based on the results of the test can not reject the hypothesis null arguing that banks with higher liquidity were not able to achieve a better performance in 2017 then banks with lower liquidity.

\section{Hypothesis Three: What is The Optimum Level of Liquidity Where We get a High Level of Profitability?}

To answer this research question is used a panel two-step GMM(Generalized Method of Moments) procedure:

Yit $=\mathrm{c}+\alpha 1 *$ Liquidityt $+\alpha 2 *$ Liquidityt $*$ Liquidityt $-1+\beta \mathrm{X}+\varepsilon$

Where,

Yit $=$ return rate, $\mathrm{ROE}$ or $\mathrm{ROA}$

$\alpha 1,2=$ estimated regression coefficients

$\mathrm{c}=$ constant 


\section{Macrothink}

$\mathrm{X}^{*} \beta$ is the matrix of variable coefficients

$\varepsilon=$ Error term.

To measure profitability through ROE, we will use two CR and TIE control variables. When ROA is used as a variable to measure profitability, we use the Capital ratio and the Debt equity ratio variables.

Table 15. Results for dependent variable ROE in Southern and Center Europa

\begin{tabular}{|c|c|c|c|c|}
\hline \multirow{2}{*}{\multicolumn{5}{|c|}{$\begin{array}{l}\text { Dependent variable: ROE } \quad \text { South Europa } \\
\text { Method: Panel Generalized Method of Moments } \\
\text { Period: } 2009-2017 \\
\text { Total observations: } 377 \\
\text { Instrument specification: CR.TIE } \\
\end{array}$}} \\
\hline & & & & \\
\hline Variables & Coeff & std err & $\mathrm{t}$ stat & p-value \\
\hline $\mathrm{C}$ & 2.148181384 & 0.041587318 & $\begin{array}{l}3.563138729 \\
-\end{array}$ & 0.000413853 \\
\hline Liquidity & -6.103513197 & 0.034929808 & 2.963463126 & 0.003236659 \\
\hline Liquidity*Liquidity & 0.222545579 & 0.00282642 & 7.976726953 & $1.85226 \mathrm{E}-14$ \\
\hline $\begin{array}{l}\text { R-squared } \\
\text { adjusted R-Squared }\end{array}$ & $\begin{array}{l}0.453483919 \\
0.348957095\end{array}$ & Durbin-Watson stat & 1.610236625 & \\
\hline Dependent variable: ROE & Central Europa & & & \\
\hline $\begin{array}{l}\text { Method: Panel Generalizec } \\
\text { Period: } 2009-2017 \\
\text { Total observations: } 224 \\
\text { Instrument specification: } \\
\end{array}$ & Method of Mon & & & \\
\hline Variables & Coeff & std err & t stat & $\mathrm{p}$-value \\
\hline $\mathrm{C}$ & 3.128313756 & 0.016633754 & 7.714058943 & $3.97244 \mathrm{E}-13$ \\
\hline Liquidity & -5.104514561 & 0.005514783 & 18.95171021 & $1.94684 \mathrm{E}-48$ \\
\hline Liquidity*Liquidity & 0.211348616 & 0.00104542 & 10.85555842 & $2.47275 \mathrm{E}-22$ \\
\hline $\begin{array}{l}\text { R-squared } \\
\text { adjusted R-Squared }\end{array}$ & $\begin{array}{l}0.578688792 \\
0.461256112\end{array}$ & Durbin-Watson stat & 1.156058778 & \\
\hline
\end{tabular}

Source: Authors' calculations. 


\section{Macrothink}

Table 16. Results for dependent variable ROA in Southern and Central Europa

\begin{tabular}{|c|c|c|c|c|}
\hline Dependent variable: ROA & \multicolumn{4}{|l|}{ South Europa } \\
\hline \multicolumn{5}{|c|}{ Method: Panel Generalized Method of Moments } \\
\hline \multicolumn{5}{|c|}{ Period: $2009-2017$} \\
\hline \multicolumn{5}{|c|}{ Total observations: 377} \\
\hline \multicolumn{5}{|c|}{ Instrument specification: Capital ratio. Debt equity ratio } \\
\hline Variables & coeff & std err & t stat & p-value \\
\hline $\mathrm{C}$ & 1.037722397 & 0.005566718 & 6.77641568 & 4.8054E-11 \\
\hline & & & - & \\
\hline Liquidity & -0.505486374 & 0.019118022 & 5.517640565 & $6.42835 \mathrm{E}-08$ \\
\hline Liquidity*Liquidity & -0.021927091 & 0.000430839 & -5.08796335 .74 & 049E-07 \\
\hline R-squared & 0.81750181 & Durbin-Watson stat & 1.332517364 & \\
\hline adjusted R-Squared & 0.76839754 & & & \\
\hline Dependent variable: ROA & Central Europa & & & \\
\hline \multicolumn{5}{|c|}{ Method: Panel Generalized Method of Moments } \\
\hline \multicolumn{5}{|c|}{ Period: $2009-2017$} \\
\hline \multicolumn{5}{|l|}{ Total observations: 224} \\
\hline \multicolumn{5}{|c|}{ Instrument specification: Capital ratio. Debt equity ratio } \\
\hline Variables & coeff & std err & t stat & p-value \\
\hline $\mathrm{C}$ & 2.008415947 & 1.010364913 & 1.987812444 & 0.048050165 \\
\hline & & & - & \\
\hline Liquidity & -0.910073299 & 0.05896631 & 15.43378408 & 4.31651E-37 \\
\hline Liquidity*Liquidity & 0.040233531 & 0.043475158 & 5.525765598 & $9.07678 \mathrm{E}-08$ \\
\hline R-squared & 0.484692371 & Durbin-Watson stat & 1.180825121 & \\
\hline adjusted R-Squared & 0.480028953 & & & \\
\hline
\end{tabular}

Source: Authors' calculations

Based on the results of tables 15, 16 we calculate the optimal level of bank liquidity, which will maximize profitability based on the maximization conditions, the equation (11) equates to 0 and the derivative.

$\mathrm{d}($ Yit $)=\mathrm{d}(\mathrm{c}+\alpha 1 *$ Liquidityt $+\alpha 2 *$ Liquidityt $*$ Liquidityt $-1+\beta * \mathrm{X}+\varepsilon)=0$ (Note 3 )

$\alpha 2 *$ Liquidityt-1 $=-\alpha 1$ Liquidityt-1optimum $=-\alpha 1 / \alpha 2$

Liquidityt-1optimum $(\mathrm{ROE})=-\alpha 1 / \alpha 2=-(-6.1035) / 0.225=27.42 \%$

Liquidityt-1optimum $(\mathrm{ROE})=-\alpha 1 / \alpha 2=-9-5.1045) / 0.2113=24 \%$

Liquidityt-1optimum $(\mathrm{ROA})=-\alpha 1 \quad / \alpha 2=-(-0.5054) / 0.0219=23.05 \%$

Liquidityt-1optimum $($ ROA $)=-\alpha 1 \quad / \alpha 2=-(-0.9100) / 0.0402=22.6 \%$

The optimum level of bank liquidity at the moment $t-1$, which will give the highest level of return on equity (ROE) is $27.42 \%$ for banks in South Europe and 24\% for banks in Central Europe. While to maximize ROA, based on equations 16, 17, for banks in South Europe the liquidity level is $23.05 \%$ and $22.6 \%$ for banks in Central Europa. 


\section{Conclusion}

The purpose of this study is to determine the impact or relationship between liquidity management and profitability in the banking sector in central and south Europe. The data were analyzed using correlation and regression analysis as well as non-parametric tests run through Real-statistic program. Based on the research findings, clarify that the current ratio (CR) and cash ratio (CRR) have a positive but weak relationship with banks profitability, when used as dependent variables for measuring banks' profitability, return on equity (ROE) and return on assets (ROA). While in the case when return on capital employed (ROCE) is used as dependent variable to measure the profitability, the explanatory variable does not show any relation to the dependent variables. The debt equity ratio has a negative and significant relationship with the dependent variable ROA. The findings show that only the Times Interest Rate (TIE) ratio shows how many times the annual interest expenses are covered by the net operating income of the company, shows a positive and strong correlation with the three variables dependent ROE, ROA, ROCE. Also, the results showed that banks with higher levels of liquidity cannot reach a higher level of profitability than banks with lower level liquidity. The results of the Mann - Whitney $U$ test showed that the high level of liquidity is not a prerequisite for achieving a high level of profitability. Mann-Whitney $U$ for Southern Europe $U=150, p=0.33>0.05$ and for central Europe $U=29, p=0.074>0.05$. Also, the optimum level of bank liquidity at the moment $\mathrm{t}-1$, which will give the highest level of return on equity (ROE) is $27.42 \%$ for banks in South Europe and $24 \%$ for banks in Central Europe. While to maximize ROA, for banks in South Europe the liquidity level is $23.05 \%$ and $22.6 \%$ for banks in Central Europe.

\section{Acknowledgement}

Acknowledgments: G. Nure acknowledges the financial support from The Einstein Foundation. I thank also my department colleagues referees for most valuable comments on an earlier draft of the paper.

\section{References}

Aburime, T. U. (2008). Determinants of Banks of Bank Profitability: Macroeconomic evidence from Nigeria. Social Science Network, Deakin University.

Akter, A., \& Mahmud, K. (2014). Liquidity-profitability relationship in Bangladesh banking industry. International Journal of empirical Finance, 2(4), 112-113.

Ali, S. A. (2015). The Effect of the Liquidity Management on Profitability in the Jordanian Commercial Banks. International Journal of Business and Management, 10(1), 62.

Amengor, E. C. (2010). Importance of Liquidity and Capital Adequacy to Commercial Banks. A Paper Presented at Introduction Ceremony of ACCE, UCC Campus.

Berger, A. N., \& Bouwman, C. H. (2008). Financial Crises and Bank Liquidity Creation. Social Science Network.

Bhunia, A., \& Khan, I. U. (2011). Liquidity management efficiency of Indian Steel 
Companies (A Case Study). Far East Journal of Psychology and Business, 3(3), 3-13.

Bordeleau, E., \& Graham, C. (2010). The Impact of Liquidity on bank profitability. Bank of Canada Working Paper ( No.2010,38).

Bourzgarru, H., Jouida, S., \& Loihichi, W. (2018). Bank profitability during and after the financial crisis: Domestic versus foreign banks. Research in International Business and Finance, 44, 26-39.

Chandra, P. (2001). Financial Management (7th ed.). McGraw-Hill.

Czekaj, J., \& Dresler, Z. (2001). Zarzadzanie Finansami Przedsiebiorstw. Warszawa:Wydawnictwo Naukowe PWN.

Emmanuel, N. R. (1997). Commercial Banking in era of Deregulation (3rd Ed.). Greenwood Publishing Group.

Fuertes, A., Osborne, M., \& Milne, A. (2009). Capital and profitability in banking: Evidence from US banks. Working Paper Series

Fuertes, A., Osborne, M., \& Milne, A. (2012). In good times and in bad: Bank capital ratios and lending rates. International Review of Financial Analysis, 35.

Gajdka, J., \& Walinska, E. (2008). Zarzadzanie finansowe. Teoria I praktyka, 2, 12.

Hirigoyen, G. (1985). Rentabilite et Solvabilite. Direction et Gestion, 3, 13-26.

Ibe, S. (2013). The impact of Liquidity Management in banking sector of Iraq: A case of Iraq Commercial banks. Journal of Finance and Bank Management, 1(1), 37-48.

Jose, M. L., Lancaster, C., \& Stevens, J. L. (1996). Corporate Retuns and Cash conversion Cycles. Journal of Economics and Finance, 20(1), 35-48.

Kashmir. (2007). Manajemen Perbankan. Rajawali Pers. Jakarta.

Khan, A., \& Muthhar Ali, R. (2016). Impact of Liquidity on profitability of commercial Banks in Pakistan: An Analysis on Banking sector in Pakistan. Global Journal of Management and Business Research, 16(1), 24.

Kosmidou, K. (2008). The determinants of banks' profits in Greece during the period of EU financial integration.

Kumar, P. (2012). Trade-off between liquidity and profitability: A case of Bharti Airtil Ltd. Evropske financiani systemy, 2, 129.

Lancaster, C., \& Stevens, J. L. (1998). Corporate Liquidity and the Significance of Earnings versus Cash Flow. Journal of Applied Business Research, 14(4), 22.

Lartey, V. C., Antwi, S., \& Boadi, E. K. (2013). The relationship between Liquidity and profitability of Listed Banks in Ghana. International Journal of Business and Social Science, $4(3), 48-56$. 
Matarazzo, D. C. (2003). Analise Financeria de Balancos. Sao Pauolo; Atlas.

Miller, K. D., \& Bromiley, P. (1990). Strategic risk and corporate performance: An analysis of alternative risk measure. Academic of Management Journal, 33, 756-779.

Morrel, P. S. (2007). Airline Finance. Burlington: Ashgate Publishing Company.

Nimer, M., Warrad, L., \& Alomri, R. (2013). The impact of liquidity on Jordanian banks profitability through return on assets. Interdisciplinary journal of Contemporary Research in Business, 5(7), 70-76.

Niresh, J. A. (2012). Trade-off between Liquidity and Profitability: A Case of Selected Manufacturing Firms in Sri Lanka. International Refereed Research Journal, 4(2), 34.

Patnaik, U. S., \& Patnaik, M. (2005). Profitability in public Sector banks. New Dehli: Sonali Publications.

Rasul, L. (2013). Impact of Liquidity on Islamic Banks Profitability: Evidence from Bangladesh. Acta Universitatis Danubius: Oeconomica, 9(2), 23-36.

Renato, S. V. (2010). An Exploratory Study of Airline Companies Between 2005-2008. International Journal of Business and Management, 10(2), 48-56.

Saleem, Q., \& Rehman, R. U. (2011). Impact of Liquidity ratios on profitability. Interdisciplinary Journal of research in Business, 1(7), 95-98.

Salim, B. F., \& Bilal, Z. O. (2016). The impact of liquidity management on financial performance in Oman banking sector. International Journal of Applied Business and Economic Research, 14(1), 545-565.

Sartono, R. A. (2001). Manajemen Keuangan Teori dan Aplikasi. Yogyakarta: BPEF.

Tosmocos, D. (2003). Equilibrium Analysis, Banking, contagion and financial Fragility. Working Paper 175, Bank of England, London, UK.

Van Ness, D. R. (2009). Corporate Performance (3rd Ed.): Strategies, Actions, Results. East Greenbush: Hallenbeck Publishing Co.

Wojciechowska, U. (2001). Plynnosc finansowa polskich przedsiebiorstw okresie transformacji gospodarki aspekty makroekonomiczne I mikroekonomiczne. Warszawa: oficyna Wydawnicza Szkoly Glownej Handlowej.

\section{Notes}

Note 1. Khan and Mutahhar Ali 2016, found that there was no significant relationship between liquidity and profitability, where CRT and ROE profitability were used as variables to measure liquidity. While Akter and Muhmund 2014, Al-Nimer et al 2013, concluded that there is a significant and positive relationship between Liquidity and Profitability when CR and Capital ratios are used as liquidity measurement variables, whereas the return on assets is 
used for profitability.

Note 3. Based on the derivatives regulation we transform the function $\mathrm{d}(\mathrm{Yit})=\mathrm{d}(\mathrm{c}+$ $\alpha 1 *$ Liquidityt $+\alpha 2 *$ Liquidityt*Liquidityt-1 $+\beta * \mathrm{X}+\varepsilon) . \mathrm{d}($ Yit $) * \mathrm{~d}($ Liquidityt $)=\mathrm{d}(\mathrm{c})$ $+\mathrm{d}($ Liquidity $(\alpha 1+\alpha 2 *$ Liquidityt -1$)+\mathrm{d}(\beta * \mathrm{X})+\mathrm{d}(\varepsilon)$

\section{Appendix}

Appendix 1. Derivations and Proofs

In this section we will present the analytical formula used in the model

Analytical Formula. $\mathrm{Rt}=\mathrm{c}+\alpha 1 *$ Liquidityt $+\alpha 2 *$ Liquidityt $*$ Liquidityt $-1+\mathrm{x} * \beta+\varepsilon(1)$

find the derivation of the function

$\mathrm{d} / \mathrm{d}(\mathrm{x})(\mathrm{Rt})=\mathrm{d} / \mathrm{d}(\mathrm{x})(\mathrm{c}+\alpha 1 *$ Liquidityt $+\alpha 2 *$ Liquidityt $*$ Liquidityt $-1+\mathrm{x} * \beta+\varepsilon)=0$

$\mathrm{d} / \mathrm{d}(\mathrm{x})(\mathrm{c})+\mathrm{d} / \mathrm{d}(\mathrm{x})(\alpha 1 *$ Liquidityt $)+\mathrm{d} / \mathrm{d}(\mathrm{x})(\alpha 2 *$ Liquidityt*Liquidityt-1) $+\mathrm{d} / \mathrm{d}(\mathrm{x})(\mathrm{x} * \beta)+$

$\mathrm{d} / \mathrm{d}(\mathrm{x})(\varepsilon)=0$

$\mathrm{d} / \mathrm{d}(\mathrm{x})(\mathrm{c})=0$

$\mathrm{d} / \mathrm{d}(\mathrm{x})(\alpha 1 *$ Liquidityt $)$, apply the constant multiple rule $\mathrm{d} / \mathrm{d}(\mathrm{x})(\alpha 1 *$ Liquidityt $),=$

$\mathrm{d} / \mathrm{d}(\mathrm{x})\left(\alpha 1^{*} \mathrm{f}\right.$ (Liquidityt )

$=\alpha 1^{*} \mathrm{~d} / \mathrm{d}(\mathrm{x}) \mathrm{f}$ (Liquidityt), with $\alpha 1=\alpha 1$ and $\mathrm{f}$ (Liquidityt ) = Liquidityt

Apply the power rule, $d / d(x)(x n)=n^{*} x n-1$, with $n=1$, in other words $d / d(x)(x)=1$

based on the above rules the equation third is transformed:

$\alpha 1 * \mathrm{~d} / \mathrm{d}(\mathrm{x})$ (Liquidityt $)=\alpha 1 * 1=\alpha 1$

$\mathrm{d} / \mathrm{d}(\mathrm{x})(\alpha 2 *$ Liquidityt*Liquidityt-1), apply the constant multiple rule. $\alpha 2 *$ Liquidityt-1

I call it a constant $\mathrm{k}$

$\mathrm{d} / \mathrm{d}(\mathrm{x})(\alpha 2 *$ Liquidityt*Liquidityt-1 $)=\mathrm{k}^{*} \mathrm{~d} / \mathrm{d}(\mathrm{x}) \mathrm{f}(\mathrm{X})$, with $\mathrm{k}=\mathrm{k}^{*} \mathrm{y}$ and $\mathrm{f}(\mathrm{X})=\mathrm{x}$

$\mathrm{d} / \mathrm{d}(\mathrm{x})(\alpha 2 *$ Liquidityt $*$ Liquidityt-1) $=\alpha 2 *$ Liquidityt- $1 * \mathrm{~d} / \mathrm{d}(\mathrm{x})$ ( Liquidityt), apply the power rule:

$\mathrm{d} / \mathrm{d}(\mathrm{x})(\mathrm{xn})=\mathrm{n} * \mathrm{xn}-1$, with $\mathrm{n}=1$, in other words $\mathrm{d} / \mathrm{d}(\mathrm{x})(\mathrm{x})=1$

$=\alpha 2 *$ Liquidityt- $1 * \mathrm{~d} / \mathrm{d}(\mathrm{x})($ Liquidityt $)==\alpha 2 *$ Liquidityt-1 (5)

$\mathrm{d} / \mathrm{d}(\mathrm{x})(\varepsilon)=0$

$d / d(x)\left(x^{*} \beta\right)=x * d / d(x)(\beta)=X^{*} 0=0$

after derivative transformations formula (1) is transformed: 


\section{Macrothink}

$\alpha 1+\alpha 2 *$ Liquidityt- $1=0$

$\alpha 2 *$ Liquidityt- $1=-\alpha 1$

Liquidityt-1 $=-\alpha 1 / \alpha 2$

\section{Copyright Disclaimer}

Copyright for this article is retained by the author(s), with first publication rights granted to the journal.

This is an open-access article distributed under the terms and conditions of the Creative Commons Attribution license (http://creativecommons.org/licenses/by/3.0/). 